\title{
\begin{tabular}{l|l} 
Jurnal Eksplorasi Akuntansi \\
Vol. 1, No 3, Seri D, Agustus 2019, Hal 1293-1306
\end{tabular} \mid $\begin{aligned} & \text { ISSN : 2656-3649 (Online) } \\
& \text { http://jea.ppj.unp.ac.id/index.php/jea/issue/view/11 }\end{aligned}$
}

\section{PENGARUH KUALITAS PELAYANAN PETUGAS PAJAK, SANKSI PERPAJAKAN, DAN BIAYA KEPATUHAN PAJAK TERHADAP KEPATUHAN WAJIB PAJAK UMKM DI KOTA PADANG}

\author{
Rexy Anugerah Pratama1, Erly Mulyani ${ }^{2}$ \\ 1) Alumni Jurusan'Akuntansi Fakultas Ekonomi, Universitas Negeri Padang \\ ${ }^{2)}$ Jurusan Akuntansi Fakultas Ekonomi, Universitas Negeri Padang \\ *Korespondensi: pratamarexy26@yahoo.com
}

\begin{abstract}
This research aims to determine whether the service quality of officers taxes, tax sanctions and tax compliance costs have a significant influence towards good compliance of MSME Taxpayers (micro, small and medium enterprises) partial or simultaneous. Data obtained from questionnaires filled out by respondents who registered with the Office of Cooperatives and MSMEs Padang. A total of 95 the questionnaire returned with a complete and processed condition. By using multiple regression techniques, the results of the study show that service quality and tax sanctions have a positive effect on MSME Taxpayer compliance. More and more both the service quality of tax officers and the increasingly heavy taxation sanctions imposed on SME Taxpayers, it will increase taxpayer compliance MSMEs. In addition, tax compliance costs have a negative effect on compliance MSME Taxpayers. The greater the tax compliance fee, the taxpayer compliance MSMEs will decline.
\end{abstract}

Keywords: service quality; penaltiee; tax compliance costs

How to cite (APA $6^{\text {th }}$ style)

Pratama, R.A., \& Mulyani, E. (2019). Pengaruh Kualitas Pelayanan Petugas Pajak, Sanksi Perpajakan, dan Biaya Kepatuhan Pajak Terhadap Kepatuhan Wajib Pajak UMKM di Kota Padang. Jurnal Eksplorasi Akuntansi, 1(3), Seri D, 1293-1306.

\section{PENDAHULUAN}

Pajak merupakan salah satu penerimaan terbesar dalam pendapatan negara Indonesia. Indonesia dalam melaksanakan pembangunan dan menjalankan pemerintahan serta perekonomian membutuhkan dana yang tidak sedikit. Pajak sebagai salah satu pendapatan negara yang cukup besar bagi Indonesia memiliki peranan penting dalam melaksanakan pembangunan dan menjalankan pemerintahan. APBN 2011 menunjukkan bahwa pajak memberikan kontribusi sebesar Rp 827.264,2 milyar dan APBN 2012 kontribusi pajak meningkat menjadi Rp 1.032,6 triliun (www.fiskal.depkeu.go.id).

Sebagai negara berkembang, pendapatan negara Indonesia masih tergolong rendah, dan upaya pemerintah untuk mengatasi hal ini ialah dengan meningkatkan Usaha Mikro, Kecil, dan Menengah (UMKM). Data Biro Pusat Statistik (BPS) menunjukkan jumlah UMKM yang 
berkembang dari tahun 2014-2016 sekitar lebih dari 57.900.000 unit dan diprediksi angka tersebut akan terus meningkat setiap tahun seiring dengan maraknya keinginan masyarakat Indonesia untuk berwirausaha.

Semakin meningkatnya jumlah Usaha Mikro, Kecil dan Menengah menjadi alasan pemerintah mengeluarkan Peraturan Pemerintah Nomor 46 tahun 2013, yang diubah kembali menjadi Peraturan Pemerintah Nomor 23 tahun 2018 tentang pajak penghasilan dari usaha yang diterima atau diperoleh Wajib Pajak yang memiliki peredaran bruto (omzet) tidak melebihi Rp 4,8 miliar yang mulanya dikenakan tarif $1 \%$ untuk seluruh UMKM diubah menjadi $0,5 \%$ untuk seluruh UMKM. Walaupun peraturan ini dibuat untuk mempermudah Wajib Pajak UMKM untuk melaksanakan kewajiban pajaknya, ternyata masih ada beberapa Wajib Pajak UMKM yang tidak patuh akan aturan pemerintah ini. Hal demikian merupakan permasalahan yang harus diselesaikan oleh petugas pajak.

Besarnya penerimaan pajak di suatu negara akan sangat ditentukan oleh tingkat kepatuhan oleh Wajib Pajak di negara tersebut. Semakin besar tingkat kepatuhan pajak maka semakin besar kemampuan negara dalam mengumpulkan pendapatan dari pajak. Teori kepatuhan pajak pertama kali diusulkan oleh Allingham dan Sandmo (1972) yang menyatakan bahwa kepatuhan pajak adalah penghasilan yang dinyatakan oleh seseorang yang dipengaruhi oleh beberapa faktor seperti jumlah pendapatan, tarif pajak, tingkat audit, dan penalti. Sementara itu, menurut organisasi untuk Kerjasama Ekonomi dan Pembangunan menyatakan perilaku membayar pajak dapat disebabkan oleh beberapa faktor, seperti : faktor industri, bisnis, dan sosiologi, faktor ekonomi dan psikologis.

\section{REVIU LITERATUR DAN HIPOTESIS \\ Teori Kepatuhan}

Teori kepatuhan (compliance theory) merupakan teori yang menjelaskan kondisi dimana seseorang taat akan suatu perintah atau aturan yang diberikan. Menurut Tahar (2014), kepatuhan perpajakan merupakan tanggung jawab kepada Tuhan bagi pemerintah dan rakyat sebagai Wajib Pajak untuk memenuhi seluruh kegiatan kewajiban perpajakannya dan melaksanakan hak perpajakannya. Kepatuhan Wajib Pajak merupakan suatu perilaku yang ditujukan pada kesadaran seorang Wajib Pajak terhadap kewajiban perpajakannya dengan berlandaskan perundang-undangan yang telah ditetapkan.

\section{Pajak}

Dasar hukum penerapan Pajak di Indonesia sesuai UUD 1945 Pasal 23a yang menyatakan bahwa "Pajak dan pungutan lain yang bersifat memaksa untuk keperluan negara diatur dengan Undang-Undang". Pajak menurut pasal 1 angka 1 UU No.28 tahun 2007 tentang ketentuan umum dan tata cara perpajakan: "Pajak adalah kontribusi wajib kepada negara yang terutang oleh orang pribadi atau badan yang bersifat memaksa berdasarkan Undang-Undang, dengan tidak mendapatkan imbalan secara langsung dan digunakan untuk keperluan negara bagi sebesarbesarnya kemakmuran rakyat.

\section{Kepatuhan Wajib Pajak}

Kepatuhan berarti tunduk atas suatu aturan atau ajaran. Jadi kepatuhan wajib pajak diartikan sebagai tunduk, patuh dan taat seorang Wajib pajak dalam melaksanakan hak dan kewajiban perpajakannya sesuai dengan peraturan perundang-undangan perpajakan (Siti Kurnia Rahayu, 2010). Safri Nurmantu dalam (Siti Kurnia Rahayu, 2010) 
menjelaskan bahwa kepatuhan perpajakan didefinisikan sebagai suatu keadaan dimana seorang Wajib pajak memenuhi seluruh kewajiban perpajakan dan melaksanakan hak perpajakannya.

\section{Kualitas Pelayanan Pajak}

Pelayanan merupakan suatu cara membantu, mengurus atau menyiapkan segala kebutuhan yang diperlukan seseorang. Fiskus merupakan petugas pajak. Jadi, pelayanan fiskus diartikan sebagai bentuk atau cara petugas pajak dalam membantu, mengurus, atau menyiapkan segala keperluan yang dibutuhkan seseorang yaitu Wajib Pajak dalam kegiatan perpajakannya (Jatmiko, 2006).

\section{Sanksi Perpajakan}

Sanksi perpajakan merupakan suatu jaminan atas ketentuan perundang-undangan perpajakan yang harus dituruti/ ditaati/ dipatuhi (Mardiasmo, 2006). Sanksi perpajakan disini dimaksud untuk menjadi alat preventif bagi Wajib pajak agar tidak melanggar norma perpajakan. Sanksi perpajakan ada dikarenakan terdapat pelanggaran terhadap peraturan perpajakan dimana semakin besar kesalahan yang dilakukan seorang Wajib pajak, semakin berat pula sanksi yang diberikan (Resmi, 2008). Contoh pelanggaran yang sering dilakukan seperti keterlambatan pembayaran pajak, kurang bayar, kesalahan dalam pengisian SPT, dan lainnya.

\section{Biaya Kepatuhan Pajak}

Biaya kepatuhan pajak merupakan pemenuhan kewajiban perpajakan yang dilakukan oleh Wajib pajak dalam rangka memberikan kontribusi untuk pembangunan dewasa ini yang diharapkan dalam pemenuhannya diberikan secara sukarela. Siti Kurnia rahayu (2010) menjelaskan bahwa biaya kepatuhan pajak merupakan biaya yang dikeluarkan oleh Wajib pajak dalam memenuhi syarat-syarat penghitungan pajak. Biaya kepatuhan pajak menurut Safri Nurmantu (2008) ialah semua biaya yang dikeluarkan baik secara fisik maupun psikis yang harus dikeluarkan Wajib pajak untuk memenuhi kewajiban perpajakannya.

\section{Pengaruh Kualitas Pelayanan Petugas Pajak Terhadap Kepatuhan Wajib Pajak UMKM}

Pelayanan pajak merupakan pelayanan publik karena yang menjalankannya ialah instansi pemerintah yang mana bertujuan untuk memenuhi kebutuhan masyarakat maupun pelaksanaan Undang-Undang dan tidak berorientasi pada laba. Pelayanan pada sektor perpajakan dapat diartikan sebagai pelayanan yang diberikan oleh petugas pajak kepada Wajib Pajak untuk membantu memenuhi kewajiban perpajakannnya. Ada 5 faktor kualitas pelayanan pajak ialah sebagai berikut: keandalan (reliability), daya tanggap (responsiveness), jaminan (assurance), empati (empathy), wujud nyata (tangibles) (Zeithaml, 2002). Petugas pajak perlu meningkatkan pelayanan pajak agar sesuai dengan ketentuan dan peraturan yang ditetapkan Undang-Undang agar menunjang kepatuhan Wajib Pajak dalam kegiatan perpajakannya dan tercapainya tujuan pemerintah dalam melaksanakan pembangunan.

Peningkatan kualitas pelayanan diharapkan dapat meningkatkan kepuasan pada Wajib Pajak sehingga meningkatkan kepatuhan pada Wajib Pajak dalam kegiatan perpajakannya. Ukuran keberhasilan penyelenggaraan pelayanan ditentukan oleh tingkat kepuasan penerima pelayanan, oleh karena itu semakin tinggi tingkat pelayanan kepada Wajib Pajak maka semakin tinggi pula tingkat kepatuhan Wajib Pajak. Penelitian yang dilakukan oleh Andriana (2011) 
menunjukkan bahwa pengaruh kualitas pelayanan pajak memiliki pengaruh positif terhadap kepatuhan Wajib Pajak. Berdasarkan penelitian dan pernyataan terdahulu, penulis merumuskan hipotesis sebagai berikut :

H1: Kualitas pelayanan petugas pajak berpengaruh positif signifikan terhadap kepatuhan Wajib Pajak UMKM

\section{Pengaruh Sanksi Perpajakan Terhadap Kepatuhan Wajib Pajak UMKM}

Perpajakan yang telah diatur didalam Undang-Undang perpajakan memiliki dasar hukum yang kuat bagi yang melanggar kegiatan perpajakan tersebut. Dalam Undang-Undang perpajakan dikenal dua macam sanksi, yaitu sanksi administrasi dan sanksi pidana. Sanksi administrasi akan diberikan apabila Wajib Pajak melakukan pelanggaran kewajiban yang telah ditentukan dalam Undang-Undang No.28 Tahun 2007 tentang Ketentuan Umum dan Tata Cara Perpajakan (UU KUP) dan dapat dikenai sanksi berupa sanksi bunga, sanksi berupa kenaikan, dan sanksi berupa denda. Sedangkan sanksi pidana berupa kurungan dan hukuman penjara.

Sanksi perpajakan ini diterapkan karena banyaknya terjadi pelanggaran terhadap UndangUndang Perpajakan yang mana menunjukkan semakin besar kesalahan seorang Wajib Pajak maka semakin besar pula denda yang didapatkannya (Resmi, 2008). Wajib Pajak akan memenuhi kewajiban perpajakannya apabila memandang bahwa sanksi perpajakan akan lebih banyak merugikannya (Nugroho, 2006), dengan demikian semakin tinggi tingkat sanksi perpajakan yang diterima Wajib Pajak maka tingkat kepatuhan Wajib Pajak juga semakin meningkat. Penelitian sebelumnya yang dilakukan oleh Arabella (2012) menunjukkan bahwa sanksi perpajakan memiliki pengaruh positif terhadap kepatuhan Wajib Pajak UMKM. Berdasarkan penelitian dan pernyataan terdahulu, penulis merumuskan hipotesis sebagai berikut :

$\mathbf{H}_{2}$ : Sanksi perpajakan berpengaruh positif signifikan terhadap kepatuhan Wajib Pajak UMKM

\section{Pengaruh Biaya Kepatuhan Pajak Terhadap Kepatuhan Wajib Pajak UMKM}

Kepatuhan atau Compliance cost merupakan biaya biaya yang dikeluarkan Wajib Pajak dalam rangka pemenuhan kegiatan kewajiban perpajakan. Biaya kepatuhan terbagi atas tiga yaitu, Direct money cost yang merupakan biaya-biaya berupa uang tunai yang dikeluarkan Wajib Pajak dalam rangka pemenuhan kewajiban perpajakannya seperti pembayaran kepada konsultan pajak. Time cost yaitu waktu yang terpakai oleh Wajib Pajak dalam melakukan kegiatan perpajakannya seperti waktu yang digunakan untuk konsultasi dengan akuntan atau konsultan pajak. Psychological cost meliputi ketidakpuasan, rasa frustasi serta keresahan Wajib Pajak dalam berinteraksi dengan sistem dan otoritas pajak (Sandford, 1989).

Biaya kepatuhan pajak merupakan biaya-biaya yang ditanggung oleh Wajib Pajak itu sendiri terkait kegiatan perpajakannya. Besarnya biaya-biaya yang harus dikeluarkan Wajib Pajak menentukan tingkat kepatuhan perpajakan. Karena Wajib Pajak telah berusaha untuk patuh maka Wajib Pajak berharap seminimal mungkin mengeluarkan biaya-biaya terkait kegiatan kewajiban perpajakannya seperti Direct money cost, Time cost, dan Psychological cost. Pada penelitian ini indikator untuk mengukur biaya kepatuhan pajak ialah Direct money cost dan Time cost. Psychological cost tidak digunakan dikarenakan memiliki sifat berbanding terbalik dengan Direct money cost dan Time cost.

Wajib pajak yang telah berupaya untuk patuh dengan membayar kewajiban perpajakannya akan sangat dirugikan apabila mendapati biaya kepatuhan pajak cukup tinggi, dengan demikian semakin tinggi biaya kepatuhan pajak maka tingkat kepatuhan Wajib Pajak akan semakin rendah. Penelitian yang dilakukan Arabella (2012) menunjukkan bahwa biaya 
kepatuhan pajak memiliki pengaruh negatif terhadap kepatuhan Wajib Pajak UMKM. Berdasarkan penelitian dan pernyataan terdahulu, penulis merumuskan hipotesis sebagai berikut: H3: Biaya kepatuhan pajak tidak berpengaruh signifikan terhadap kepatuhan Wajib Pajak UMKM

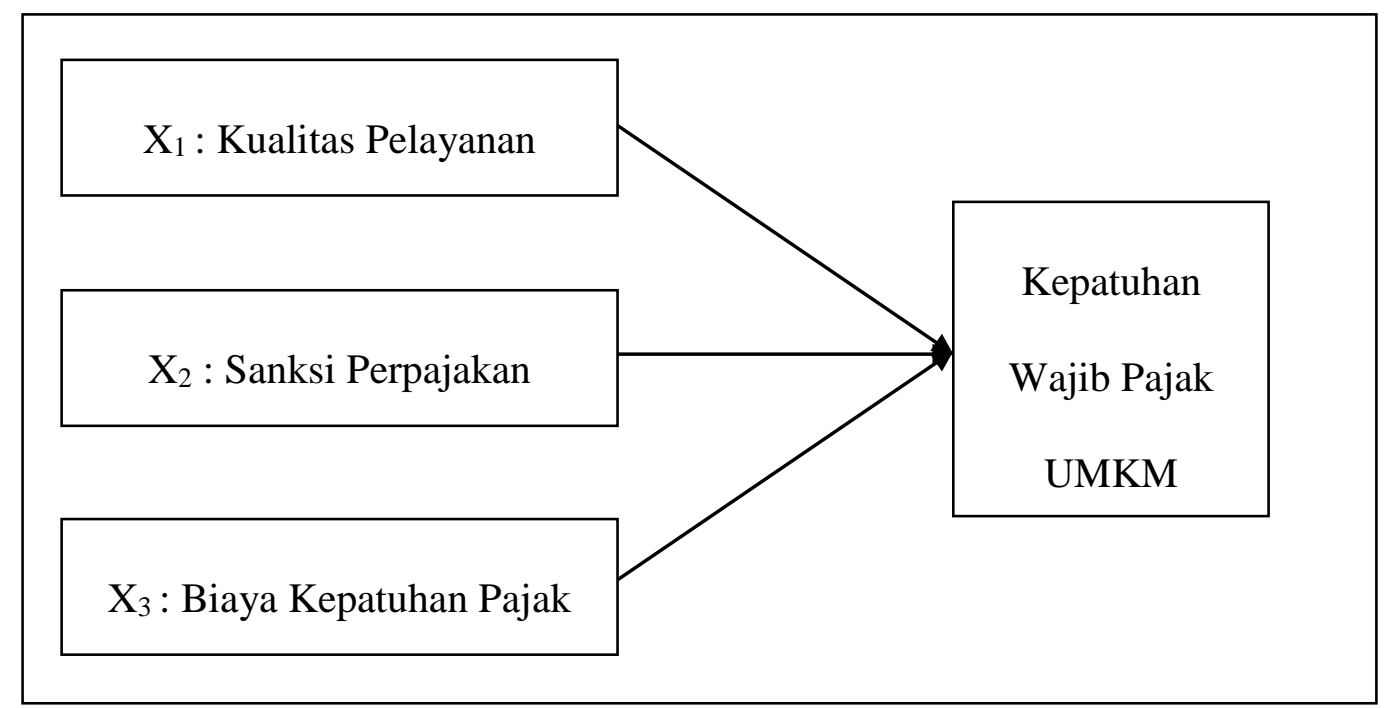

\section{METODE PENELITIAN \\ Desain penelitian}

Penelitian ini merupakan penelitian dengan pendekatan kuantitatif yang mana penelitian ini bertujuan untuk menggambarkan dan menguji secara empiris pengaruh variabel bebas yang terdiri atas kualitas pelayanan, sanksi perpajakan dan biaya kepatuhan pajak dengan variabel terikat yaitu kepatuhan wajib pajak Usaha Mikro Kecil dan Menengah (UMKM) dan penelitian ini dilakukan di kota Padang.

\section{Populasi, Sampel, dan Teknik pengambilan sampel}

Populasi yang diambil untuk melakukan penelitian ini adalah Wajib Pajak Usaha Mikro Kecil dan Menengah (UMKM) di Kota Padang berjumlah 2034 UMKM. Sampel pada penelitian ini ialah Wajib Pajak Usaha Mikro Kecil dan Menengah (UMKM) di kota Padang yang memiliki Nomor Pokok Wajib Pajak (NPWP) dan Nomor Pengukuhan Pengusaha Kena Pajak (NPPKP). Penentuan banyaknya sampel penelitian ditentukan menggunakan rumus Slovin (Umar, 2007)

\section{Jenis, Sumber Data, dan Teknik pengumpulan data}

Dalam memperoleh data pada penelitian ini peneliti menggunakan dua cara yaitu penelitian lapangan (field research) sebagai data primer dan penelitian kepustakaan (library research) sebagai data sekunder. Pengumpulan data dilakukan dengan cara survey kuesioner yaitu pengumpulan data melalui pemberian daftar pertanyaan dan dilengkapi dengan beberapa alternatif jawaban kepada responden. 


\section{Instrumen variabel penelitian}

a. Kepatuhan Wajib Pajak (Y)

Kepatuhan pajak dapat diartikan bahwa Wajib Pajak bersedia untuk memenuhi kewajiban pepajakannya sesuai dengan aturan yang berlaku tanpa perlu dilakukannya pemeriksaan, investigasi, peringatan ataupun ancaman dan penerapan sanksi.

b. Kualitas Pelayanan (X1)

Pelayananan merupakan bentuk kegiatan yang dilaksanakan oleh Kantor Pelayanan Pajak Pratama Padang sebagai bentuk upaya pemenuhan kebutuhan Wajib Pajak dalam rangka pelaksanaan kegiatan perpajakan yang sesuai dengan Undang-Undang dan bertujuan untuk menjaga kepuasan Wajib Pajak itu sendiri.

c. Sanksi Perpajakan (X2)

Sanksi perpajakan timbul karena adanya pelanggaran terhadap peraturan perundangundangan perpajakan yang berlaku. Sehingga apabila terjadi pelanggaran maka Wajib Pajak akan dikenai sanksi yang sesuai dengan ketetapan perpajakan yang berlaku.

d. Biaya Kepatuhan Pajak (X3)

Biaya kepatuhan pajak merupakan biaya yang dikeluarkan oleh Wajib Pajak dalam rangka pemenuhan kewajiban perpajakannya. Indikator variabel ini adalah direct money cost, time cost, pshycological cost.

\section{HASIL DAN PEMBAHASAN}

\section{Analisis Induktif}

\section{a. Uji Asumsi Klasik}

\section{Uji Normalitas}

Uji normalitas digunakan untuk menguji apakah distribusi data mengikuti atau mendekati distribusi normal. Data yang baik adalah data yang pola distribusinya normal. Uji normalitas dapat dilakukan dengan metode Kolmogorav-Smirnov test. Hasil pengolahan SPSS versi 21 didapat bahwa hasil uji normalitas menunjukkan level signifikasi lebih besar dari $\alpha(\alpha=$ 0,05 ) yaitu 0,200>0,05 sehingga data terdistribusi secara normal seperti tabel dibawah ini:

Tabel 4.10

Uji Normalitas

\begin{tabular}{|c|c|c|}
\hline \multicolumn{3}{|c|}{ One-Sample Kolmogorov-Smirnov Test } \\
\hline & & $\begin{array}{c}\text { Unstandardize } \\
\text { d Residual }\end{array}$ \\
\hline \multicolumn{2}{|l|}{$\mathrm{N}$} & 95 \\
\hline \multirow[t]{2}{*}{ Normal Parameters ${ }^{\mathrm{a}, \mathrm{b}}$} & Mean & .0000000 \\
\hline & Std. Deviation & 2.63132331 \\
\hline \multirow{3}{*}{$\begin{array}{ll}\text { Most } & \text { Extreme } \\
\text { Differences } & \end{array}$} & Absolute & .062 \\
\hline & Positive & .059 \\
\hline & Negative & -.062 \\
\hline \multicolumn{2}{|l|}{ Test Statistic } & .062 \\
\hline Asymp. Sig. (2-tailed) & & $200^{\mathrm{c}, \mathrm{d}}$ \\
\hline \multicolumn{3}{|c|}{ a. Test distribution is Normal. } \\
\hline \multicolumn{3}{|l|}{ b. Calculated from data. } \\
\hline \multicolumn{3}{|c|}{ c. Lilliefors Significance Correction. } \\
\hline \multicolumn{3}{|c|}{ d. This is a lower bound of the true significance. } \\
\hline
\end{tabular}

Sumber: Data Primer yang diolah tahun 2019 


\section{Uji Multikolenearitas}

Tabel 4.11

Uji Multikolinearitas

\begin{tabular}{|c|c|c|}
\hline \multirow{2}{*}{ Model } & \multicolumn{2}{|c|}{ Collinearity Statistics } \\
\cline { 2 - 3 } & Tolerance & VIF \\
\hline (Constant) & & \\
\hline X1 & .989 & 1.012 \\
\hline X2 & .989 & 1.012 \\
\hline X3 & 1.000 & 1.000 \\
\hline
\end{tabular}

Sumber: Data primer yang diolah, 2019

Berdasarkan tabel 4.11 di atas dapat dilihat variabel Kualitas pelayanan petugas pajak dengan nilai (VIF) 1,012 dan tolerance 0,989, variabel Sanksi perpajakan dengan nilai (VIF) 1,012 dengan tolerance 0,989, dan variabel Biaya kepatuhan memiliki nilai (VIF) 1,000 dan tolerance 1,000. Dengan demikian dapat dikatakan tidak terdapat korelasi variabel-variabel bebas antara satu dengan yang lainnya, atau variabel independen pada penelitian ini bebas dari gejala multikolinearitas.

\section{Uji Heteroskedastisitas}

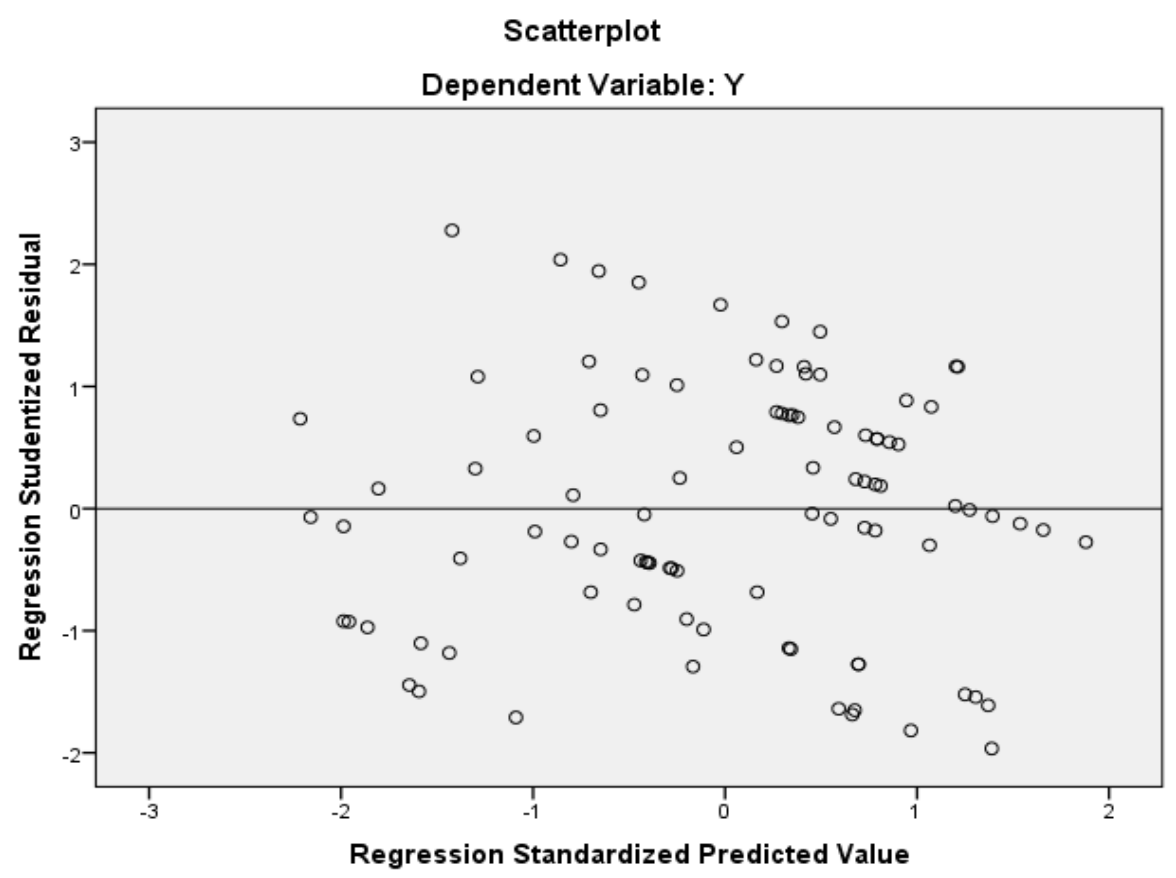

Grafik 4.1 Uji

Uji Heterokedastisitas

Gambar di atas menunnjukkan tidak terdapat pola tertentu pada grafik scatterplot antara SRESID dan ZPRED dimana sumbu Y adalah residual (Y prediksi-Y sesungguhnya) yang telah distandardized. Jadi tidak ada pola yang jelas, serta titik menyebar di atas dan di bawah angka 0 pada sumbu $\mathrm{Y}$, maka dapat disimpulkan tidak terjadi heterokedastisitas dan layak untuk diteliti. 
b. Uji Hipotesis

1. Analisis Regresi Berganda

Tabel 4.12

\begin{tabular}{|c|c|c|c|c|c|c|}
\hline \multicolumn{7}{|c|}{ Coefficients $^{\mathrm{a}}$} \\
\hline \multirow{2}{*}{\multicolumn{2}{|c|}{ Model }} & \multicolumn{2}{|c|}{$\begin{array}{l}\text { Unstandardized } \\
\text { Coefficients }\end{array}$} & \multirow{2}{*}{$\begin{array}{c}\text { Standardized } \\
\text { Coefficients } \\
\text { Beta }\end{array}$} & \multirow[b]{2}{*}{$\mathrm{T}$} & \multirow{2}{*}{ Sig. } \\
\hline & & B & $\begin{array}{l}\text { Std. } \\
\text { Error }\end{array}$ & & & \\
\hline \multirow[t]{4}{*}{1} & (Constant) & 18.922 & 3.615 & & 5.235 & .000 \\
\hline & $\mathrm{X} 1$ & .233 & .066 & .344 & 3.543 & .001 \\
\hline & $\mathrm{X} 2$ & .171 & .073 & .228 & 2.347 & .021 \\
\hline & $\mathrm{X} 3$ & .010 & .093 & .011 & .113 & .911 \\
\hline
\end{tabular}

a. Dependent Variable: $\mathrm{Y}$

Sumber: Data primer yang diolah, 2019

Berdasarkan tabel 4.12 di atas dapat dianalisis model persamaaan sebagai berikut:

$$
\mathrm{Y}=18,922+0,233 \times 1+0,171 \times 2+0,010 \times 3+e
$$

Keterangan:

$\mathrm{Y}=$ Kepatuhan Wajib Pajak UMKM

$\mathrm{X}_{1}=$ Kualitas Pelayanan Petugas Pajak

$\mathrm{X}_{2}=$ Sanksi Perpajakan

$\mathrm{X}_{3}=$ Biaya Kepatuhan Pajak

Berdasarkan persamaan regresi di atas dapat dijelaskan sebagai berikut :

a) Konstanta $(\alpha)$

Hasil uji analisis regresi berganda terlihat bahwa konstanta sebesar 18,922 menunjukkan bahwa tanpa adanya pengaruh dari variabel bebas yaitu Kualitas pelayanan petugas pajak, Sanksi perpajakan, Biaya kepatuhan pajak maka Kepatuhan Wajib Pajak UMKM akan benilai sebesar 18,922 .

b) Koefisien regresi ( $\beta$ ) Kualitas Pelayanan Petugas Pajak

Koefisien Kualitas pelayanan petugas pajak diperoleh sebesar 0,233 hal ini menunjukkan jika variabel Kualitas pelayanan petugas pajak meningkat satu satuan maka Kepatuhan Wajib Pajak UMKM akan meningkat sebesar 0,233 dengan variabel variabel lain konstan.

c) Koefisien regresi ( $\beta$ ) Sanksi Perpajakan

Koefisien Sanksi perpajakan diperoleh sebesar 0,171 hal ini menunjukkan jika variabel Sanksi Perpajakan meningkat satu satuan maka variabel Kepatuhan Wajib Pajak UMKM akan meningkat sebesar 0.171 dengan asumsi variabel lain konstan. 


\section{d) Koefisien regresi ( $\beta$ ) Biaya Kepatuhan Pajak}

Koefisien Biaya Kepatuhan Pajak diperoleh sebesar 0,010 hal ini menunjukkan jika variabel Biaya Kepatuhan Pajak meningkat satu-satuan maka variabel Kepatuhan Wajib Pajak UMKM meningkat sebesar 0,010 dengan asumsi variabel lain konstan.

\section{c. Uji Kelayakan Model}

\section{Koefisien Determinasi $R^{2}$}

Tabel 4.13

Uji Adjusted $R^{2}$

\begin{tabular}{|l|c|r|r|r|}
\hline \multicolumn{5}{|c|}{ Model Summary } \\
\hline Model & $\mathrm{R}$ & R Square & $\begin{array}{c}\text { Adjusted R } \\
\text { Square }\end{array}$ & $\begin{array}{c}\text { Std. Error of } \\
\text { the Estimate }\end{array}$ \\
\hline 1 & $.392^{\mathrm{a}}$ & .153 & .126 & 2.67435 \\
\hline a. Predictors: (Constant), X3, X1, X2 \\
\hline \multicolumn{2}{|l}{ b. Dependent Variable: Y } \\
\hline
\end{tabular}

Sumber: Data primer yang diolah, 2019

Berdasarkan tabel 4.13 di atas besarnya Adjusted $R$ Square adalah 0,126. Hal ini mengidentifikasikan bahwa konstribusi variabel independen terhadap variabel dependen adalah sebesar $12,6 \%$, sedangkan $87,4 \%$ lainya ditentukan oleh faktor lain di luar model yang tidak terdeteksi dalam penelitian ini.

\section{Uji F}

Berdasarkan hasil analisis data yang diperoleh menguji hipotesis ini, maka dilakukan uji $\mathrm{F}$ dengan membandingkan nilai $F_{\text {hitung }}$ dengan $F_{\text {tabel. }}$ Pada level signifikansi 0,05, besar $F_{\text {tabel }}$ untuk $\mathrm{n}=95$ adalah 2,70. Hasil pengolahan statistik analisis regresi menunjukkan nilai $\mathrm{F}=5,498$ dan signifikan pada level 0,002. Jadi $\mathrm{F}_{\text {hitung }}>\mathrm{F}_{\text {tabel }}$ yaitu 5,498 $>2,70$ (sig. 0,002 <0,05). Hal ini menunjukkan bahwa model regresi dapat digunakan untuk menguji pengaruh variabel independen terhadap variabel dependen. Hasil analisis data yang diperoleh tentang kualitas pelayanan petugas pajak, sanksi perpajakan, dan biaya kepatuhan pajak terhadap kepatuhan wajib pajak UMKM, uji F dapat dilihat pada Tabel 4.14 berikut ini.

Tabel 4.14

\begin{tabular}{|c|c|c|c|c|c|c|}
\hline \multicolumn{7}{|c|}{ ANOVA $^{\mathrm{a}}$} \\
\hline \multicolumn{2}{|c|}{ Model } & \multirow{2}{*}{$\begin{array}{l}\begin{array}{l}\text { Sum of } \\
\text { Squares }\end{array} \\
117.957\end{array}$} & \multirow[t]{2}{*}{ Df } & \multirow{2}{*}{$\begin{array}{r}\text { Mean Square } \\
39.319\end{array}$} & \multirow{2}{*}{$\begin{array}{l}F \\
5.498 \\
\end{array}$} & \multirow{2}{*}{$\frac{\text { Sig. }}{.002^{\mathrm{b}}}$} \\
\hline \multirow[t]{3}{*}{1} & Regression & & & & & \\
\hline & Residual & 650.843 & 91 & 7.152 & & \\
\hline & Total & 768.800 & 94 & & & \\
\hline
\end{tabular}

Sumber: Data primer yang diolah, 2019

\section{Uji Hipotesis (t-test)}

Uji t statistik (t-test) bertujuan untuk mengetahui hubungan yang signifikan dari masing-masing variabel bebas terhadap variabel terikatnya. Pengujian hipotesis secara parsial dilakukan dengan 
cara membandingkan nilai $t_{\text {hitung }}$ dengan nilai $t_{\text {tabel. }}$. Nilai $t_{\text {tabel }}$ adalah $\alpha=0,05$ dengan derajat bebas $(\mathrm{db})=\mathrm{n}-\mathrm{k}=95-4=91$ adalah 1,986, berdasarkan hasil analisis pada tabel 4.12 maka dapat diketahui pengaruh variabel independen secara parsial terhadap variabel dependen adalah sebagai berikut.

\section{Hipotesis 1}

Pengujian hipotesis dilakukan dengan membandingkan $t_{\text {hitung }}$ dengan nilai $t_{\text {tabel. }}$. Hipotesis diterima jika $t_{\text {hitung }}>t_{\text {tabel }}$ atau nilai sig $<0,05$. Nilai $t_{\text {tabel }}$ pada $\alpha=0,05$ adalah 1,986 . Variabel kualitas pelayanan petugas pajak nilai thitung adalah 3,543 dan nilai sig adalah 0,001. Dengan demikian dapat dikatakan bahwa $t_{\text {hitung }}>t_{\text {tabel }}$ yaitu 3,543 $<1,986$ atau nilai signifikasi 0,001 < 0,05. Nilai koefisien $\beta$ dari variabel kualitas pelayanan petugas pajak bernilai positif yaitu 0,233 . Hal ini menunjukkan bahwa penelitian ini membuktikan kualitas pelayanan petugas pajak berpengaruh terhadap kepatuhan wajib pajak UMKM. Dengan demikian hipotesis pertama $\left(\mathrm{H}_{1}\right)$ diterima.

\section{Hipotesis 2}

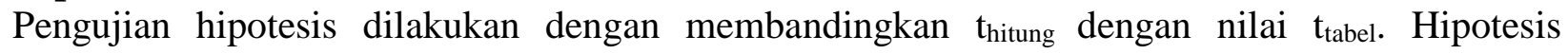
diterima jika $t_{\text {hitung }}>t_{\text {tabel }}$ atau nilai sig $<0,05$. Nilai $t_{\text {abel }}$ pada $\alpha=0,05$ adalah 1,986. Variabel sanksi perpajakan nilai thitung adalah 2,347 dan nilai sig adalah 0,021. Dengan demikian dapat dikatakan bahwa thitung $>t_{\text {tabel }}$ yaitu $2,347>1,986$ atau nilai signifikasi $0,021<0,05$. Nilai koefisien $\beta$ dari variabel sanksi perpajakan bernilai positif yaitu 0,171 . Hal ini menunjukkan bahwa penelitian ini membuktikan sanksi perpajakan berpengaruh positif signifikan terhadap kepatuhan wajib pajak UMKM. Dengan demikian hipotesis Kedua $\left(\mathrm{H}_{2}\right)$ diterima.

\section{Hipotesis 3}

Pengujian hipotesis dilakukan dengan membandingkan thitung dengan nilai $t_{\text {tabel. Hipotesis }}$ diterima jika $t_{\text {hitung }}>t_{\text {tabel }}$ atau nilai sig $<0,05$. Nilai $t_{\text {abel }}$ pada $\alpha=0,05$ adalah 1,986. Variabel biaya kepatuhan pajak nilai thitung adalah 0,113 dan nilai sig adalah 0,911. Dengan demikian dapat dikatakan bahwa $t_{\text {hitung }}<t_{\text {tabel }}$ yaitu $0,113<1,986$ atau nilai signifikasi $0,911>0,05$. Nilai koefisien $\beta$ dari variabel sanksi perpajakan bernilai positif yaitu 0,010. Hal ini menunjukkan bahwa penelitian ini tidak dapat membuktikan biaya kepatuhan pajak berpengaruh positif signifikan terhadap kepatuhan wajib pajak UMKM. Dengan demikian hipotesis Ketiga $\left(\mathrm{H}_{3}\right)$ ditolak.

\section{PEMBAHASAN}

Pengaruh Kualitas Pelayanan Petugas Pajak Terhadap Kepatuhan Wajib Pajak UMKM

Hasil penelitian membuktikan bahwa variabel kualitas pelayanan petugas pajak berpengaruh signifikan positif terhadap kepatuhan wajib pajak UMKM. Semakin tinggi tingkat kualitas pelayanan petugas pajak maka semakin tinggi pula tingkat kepatuhan wajib pajak UMKM. Hal ini ditunjukkan pada hasil uji t yang menunjukkan nilai signifikan sebesar 0,001 (Sig. < 0,05). Penelitian ini konsisten dengan penelitian Karsimiati (2009), Utama (2011), Arabella (2012), Nurita (2015). Tingkat kualitas pelayanan petugas pajak menjadi sangat berpengaruh dimata Wajib pajak dikarenakan setiap informasi dan kenyamanan yang diterima oleh Wajib pajak didasarkan atas tingkat pelayanan yang diberikan oleh petugas pajak. Semakin tinggi Tingkat kualitas pelayanan petugas pajak maka semakin tinggi pula tingkat kepatuhan Wajib pajak UMKM dalam melaksanakan kewajiban perpajakannya. 


\section{Pengaruh Sanksi Perpajakan Terhadap Kepatuhan Wajib Pajak UMKM}

Hasil penelitian membuktikan bahwa variabel Sanksi perpajakan berpengaruh terhadap kepatuhan wajib pajak UMKM. Hal ini ditunjukkan pada hasil uji t dengan tingkat signifikan sebesar 0,021 (Sig. < 0,05). Dengan demikian variabel sanksi perpajakan merupakan variabel yang mendukung tingkat kepatuhan Wajib pajak UMKM. Penelitian ini konsisten dengan penelitian yang dilakukan oleh Utama (2011) dan Arabella (2012). Adanya pengaruh sanksi perpajakan terhadap kepatuhan wajib pajak UMKM disebabkan karena adanya unsur memaksa dan mengikat dari sanksi pajak itu sendiri. Sanksi yang dikenakan terhadap wajib pajak yang tidak memenuhi kewajiban perpajakannya diatur dalam Undang-Undang perpajakan, sehingga jika wajib pajak melanggar atau tidak patuh akan dikenakan sanksi sesuai pelanggaran yang dilakukan dan akhirnya wajib pajak akan memandang bahwa sanksi perpajakan lebih banyak merugikannya.

\section{Pengaruh Biaya Kepatuhan Pajak Terhadap Kepatuhan Wajib Pajak UMKM}

Hasil penelitian ini membuktikan bahwa variabel biaya kepatuhan pajak tidak berpengaruh terhadap kepatuhan wajib pajak UMKM. Hal ini ditunjukkan pada hasil uji t dengan tingkat signifikan sebesar 0,911 (Sig. > 0,05). Hasil penelitian ini sejalan dengan penelitian yang dilakukan oleh Utama (2011) yang menjelaskan bahwa biaya kepatuhan pajak tidak berpengaruh terhadap kepatuhan wajib pajak UMKM. Tidak adanya pengaruh signifikan antara biaya kepatuhan pajak terhadap tingkat kepatuhan wajib pajak UMKM di kota Padang pada penelitian ini disebabkan karena rata-rata tingkat pemahaman dan pengetahuan wajib pajak sudah cukup baik, jadi hal yang berkaitan dengan biaya yang dikeluarkan wajib pajak dalam rangka pemenuhan kegiatan kewajiban perpajakannya sudah bukan menjadi alasan wajib pajak enggan membayar pajaknya.

\section{KESIMPULAN, KETERBATASAN, SARAN \\ Kesimpulan}

Berdasarkan hasil pengolahan dan analisis data yang telah peneliti lakukan sebelumnya, maka dapat ditarik kesimpulan :

a. Kualitas pelayanan petugas pajak berpengaruh positif terhadap kepatuhan Wajib pajak UMKM.

b. Sanksi perpajakan berpengaruh positif terhadap kepatuhan Wajib pajak UMKM.

c. Biaya kepatuhan pajak tidak berpengaruh positif terhadap kepatuhan Wajib pajak UMKM.

\section{Keterbatasan}

Peneliti telah berusaha merancang dan mengembangkan penelitian sedemikian rupa. Namun, masih terdapat beberapa keterbatasan dalam penelitian ini yang masih perlu diperbaiki bagi peneliti selanjutnya antara lain :

a. Penelitian ini hanya terbatas pada Wajib pajak UMKM yang ada di kota Padang sehingga tidak bisa dijadikan patokan untuk hasil keseluruhan pada wilayah lainnya di Sumatera Barat .

b. Masih terbatasnya jumlah responden yakni berjumlah 95 responden yang belum mencerminkan jumlah keseluruhan UMKM yang ada di kota Padang.

c. Penelitian hanya menggunakan 3 (Tiga) variabel bebas yang belum dapat menjelaskan pengaruh terhadap variabel terikat secara keseluruhan. 


\section{Saran}

Berdasarkan hasil dan keterbatasan dalam penelitian ini, penulis dapat memberikan beberapa saran yang dapat dipertimbangkan untuk mendapatkan hasil yang lebih baik lagi, antara lain sebagai berikut :

a. Diharapkan agar dapat memperluas wilayah penelitian mencakup UMKM untuk seluruh wilayah yang ada di Sumatera Barat agar penelitian dapat di generalisasi.

b. Menambah jumlah sampel yang sebelumnya hanya dapat peneliti kumpulkan sejumlah 95 sampel, agar sampel yang digunakan menjadi lebih beragam dan hasil penelitian yang didapat lebih menggambarkan keadaan sebenarnya.

c. Menambah jumlah variabel penelitian diluar variabel yang telah peneliti gunakan agar lebih mampu menjelaskan pengaruh terhadap kepatuhan wajib pajak UMKM.

\section{DAFTAR PUSTAKA}

Allingham, Michael G dan Agnar Sandmo.1972. Income Tax Evasion:A theoritical analysis. Journal of Public Economics. Vol.1 : 323-328

Andriana, Ateng.2011. Analisis atas penerapan self assesment system dan kualitas pelayanan pajak terhadap peningkatan kepatuhan formal wajib pajak pada KPP Pratama Kota Bandung.

Arabella. 2012. Skripsi: Pengaruh kualitas pelayanan petugas pajak,sanksi perpajakan dan biaya kepatuhan terhadap kepatuhan wajib pajak UMKM. Universitas kristen Petra.

Atawodi, Ojochogwu Winnie dan Stephen Aanu Ojeka.2012. Factors that affect tax compliance among small and medium enterprise in North Central Nigeria. International journal of business and management.Vol.7 No.12 : 87-96

B. Ilyas, Wirawan dan Richard Burton.2010. Hukum pajak. Jakarta: Salemba empat.

Das-Gupta, A.2004. tax administration reform and tax payer compliance in india, 575-600.

Devano, Sony dan Siti Kurnia Rahayu.200. Perpajakan konsep, Teori dan Isu. Jakarta: Kencana Prenada media grup.

Djajadiningrat.2011. Perpajakan Indonesia.Jakarta: Salemba Empat.

Ghozali, Imam. 2005. Aplikasi Analisis Multivariate dengan Program SPSS, Edisi Ketiga, Badan Penerbit Universitas Diponegoro, Semarang.

Jatmiko, A. N. 2006. Pengaruh Sikap Wajib pajak pada pelaksanaan sanksi denda,pelayanan fiskus, dan kesadaran perpajakan terhadap kepatuhan wajib pajak : Studi Empiris terhadap wajib pajak orang pribadi di Kota Semarang, TesisProgram Pasca Sarjana Magister Akuntansi Universitas Diponegoro. Semarang.

Karsimiati.2009. pengaruh pelayanan fiskus,sanksi denda dan kesadaran perpajakanterhadap kepatuhan wajib pajak dalam membayar PBB di kecamatan Gabus-Pati.

Kotler.2005.Manajemen pemasaran, Jilid I dan II. Jakarta: PT. Indeks.

Latuperissa, Wanda. 2009. Pengaruh Persepsi Wajib Pajak Orang Pribadi AtasPengenaan Sanksi Perpajakan Terhadap Meminimalisasikan Tindakan Tax Evasion. Skripsi Sarjana Jurusan Akuntansi, Fakultas ekonomi, UniversitasKomputer Indonesia.

Manalu, Lasmauli Nurita. 2012. Pengaruh Kualitas Pelayanan Terhadap KepuasanWajib Pajak Pada Dinas Pengelolaan Keuangan dan Aset Daerah kota Binjai. Thesis Pascasarjana Jurusan Ilmu Manajemen, Universitas sumatera Utara.

Mardiasmo. 2008. Perpajakan. Edisi Revisi 2011. Yogyakarta: Andi Offset. 
Marti, Lumumba Omweri dan Migwi S. Wanjohi.2011. Taxpayers attitude and tax compliance behaviour in Kenya, How the taxpayers attitude influence compliance behaviour among SMEs business income earners in Kerugoya town, Kirinyaga district. African journal of business and management. Vol.1 : 112-122.

Muliari, Ni Ketut dan Putu Ery Setiawan. 2011. Pengaruh Persepsi Tentang SanksiPerpajakan dan Kesadaran Wajib Pajak Pada Kepatuhan Pelaporan Wajib Pajak Orang Pribadi di KPP Denpasar Timur. Jurnal akuntasi bisnis Vol.6.1-Jan 2011.

Mustika utama, I Wayan.2011. Pengaruh kualitas pelayanan, sanksi perpajakan, dan biaya kepatuhan terhadap kepatuhan wajib pajak. Fakultas Ekonomi Universitas Udayana. Bali.

Nugroho,Agus. 2006. Pengaruh sikap wajib pajak pada pelaksanaan sanksidenda,pelayanan fiskus dan kesadaran perpajakan terhadap kepatuhan wajib pajak (studi empiris terhadap wajib pajak orang pribadi di Kota Semarang).Tesis Magister Akuntansi Program Pascasarjana Universitas Diponegoro.

Prasetyo, Adinur.2008. pengaruh uniformity dan kesamaan persepsi serta ukuran perusahaan terhadap kepatuhan pajak. Disertasi FISIP Universitas Indonesia.

Rahayu, Siti Kurnia. 2010. "Perpajakan Indonesia”. Yogyakarta: Edisi Pertama Graha Ilmu. Yogyakarta.

Risnawati.2009. Pengaruh kualitas pelayanan pajak terhadap kepatuhan wajib pajakpenghasilan orang pribadi. Jurnal ekonomi dan informatika.

Republik Indonesia, "Undang-Undang RI Nomor 28 Tahun 2007 tentang perubahanketiga atas Undang-Undang Nomor 6 Tahun 1983 Tentang Ketentuan Umum dan Tata Cara Perpajakan”, Pemerintah RI, Jakarta, 2007.

Republik Indonesia. 2008. Undang-Undang No. 20 Tahun 2008Tentang Usaha Mikro, Kecil dan Menengah. Pemerintah RI. Jakarta.

Republik Indonesia. 2013. "PP No 46 Tahun 2013 Tentang Pajak Penghasilan AtasPenghasilan Dari Usaha yang Diterima atau Diperoleh Wajib Pajak yang Memiliki Peredaran Bruto Tertentu. Pemerintah RI. Jakarta.

Republik Indonesia. 2013. "PMK No 107 tahun 2013 Tentang Pelaksanaan PP No46 tahun 2013. Kementrian Keuangan. Jakarta.

Republik Indonesia. 2018. "PP No 23 Tahun 2018 Tentang Pajak Penghasilan AtasPenghasilan Dari Usaha yang Diterima atau Diperoleh Wajib Pajak yang Memiliki Peredaran Bruto Tertentu. Pemerintah RI. Jakarta.

Rosdiana, Haula dan Edi Slamet Irianto.2011. Panduan lengkap tata cara perpajakan di Indonesia.Jakarta: Visimedia Pustaka

Saad, Natrah.2012. Perceptions of tax fairness and tax compliance behaviour: A Comparative study. Jurnal pengurusan Vol.36 : 89-100.

Sandford, Cedric.1989. Administrative and tax compliance costs of taxation. Dalam Sandford.

Simanjuntak, Timbul dan Imam Mukhlis.2012. Analysis of tax compliance and impact on regional budgeting and public walfare. International journal of administrative science and organization. Vol.19 No.3 : 194-205.

Soemitro, Rochmat. 2008. Asas dan Dasar Perpajakan 1. Bandung : Eresco

Supriyati dan Nurhidayati.2008. Pengaruh pengetahuan pajak dan persepsi Wajib pajak terhadap kepatuhan pajak. Jurnal Akuntansi dan Teknologi informasi, Vol.7 No.1.

Sutedi.2011. Hukum pajak. Jakarta:Sinar Grafika.

Tahar, Rachman.2014. Pengaruh faktor internal dan faktor eksternal terhadap kepatuhan Wajib pajak. Jurnal akuntansi dan investasi, Vol.12 No.1 57-67. 
Widodo.2010. Moralitas, Budaya, dan Kepatuhan Pajak. Bandung: Alfabeta.

Yadnyana, I Ketut.2009. Pengaruh moral dan sikap wajib pajakpada kepatuhan wajib pajak koperasi di kota Denpasar. Denpasar:Fakultas Ekonomi Udayana.

Zeithaml, Valerie A.2002. Service marketing. McGraw Hill Inc, New York.

www.fiskal.depkeu.go.id. Diakses pada tanggal 18 Januari 2019. 